\title{
Occurrence of thin, metal-rich layers in deep-sea sediments: a geochemical characterization of copper remobilization
}

\author{
Bertil van Os, ${ }^{*}$ Hendrik-J $J_{\text {AN Visser, }}$, Jack $_{\text {J }}$. Middelburg $\dagger$ and \\ Gert J. DE LANGE *
}

(Received 12 August 1992; in revised form 19 January 1993; accepted 2 February 1993)

\begin{abstract}
Distinctly coloured trace metal enriched fronts with a six-fold $\mathrm{Cu}$-enrichment occur in the interbedded pelagic-turbiditic sediments from the Madeira Abyssal Plain. To decipher their mode of formation, two sequential extraction techniques, an acid-gradient and a "Tessier-type" scheme, were applied. Two different front types could be distinguished: Type- 1 fronts are mostly black and enriched in $\mathrm{Co}, \mathrm{Zn}, \mathrm{Ni}$ and $\mathrm{Cu}$, and associated with the oxidation fronts that developed after deposition of turbidites. Type-2 fronts are purple, extremely enriched in $\mathrm{Cu}$, and associated with sulphur. These fronts are sometimes found in relation with a relict oxidation front, but often show no clear relation with lithology. Two different modes of formation are postulated. (1) The transition-metal enrichment in the type-1 fronts is typical for a manganese-oxide association often found in marine sediments. After the dissolution of manganese-oxide during sub-oxic diagenesis, the transition metals were liberated and subsequently relocated and precipitated in response to a redox-gradient. (2) The $\mathrm{Cu}-\mathrm{S}$ association in type-2 fronts is also formed during sub-oxic diagenesis. The main process leading to the formation of this $\mathrm{Cu}-\mathrm{S}$ enrichment is the mobilization of inherited $\mathrm{Cu}-\mathrm{S}$ compounds from organic-rich turbidites. The accumulation of these compounds is possibly related to redox changes at relict oxidation fronts and to gradual. probably slowly evolving, redox changes that occur at present.
\end{abstract}

\section{INTRODUCTION}

TRACE metal behaviour in pelagic deep-sea sediments has received increasing attention, especially since the discovery of Mn-nodules covering large parts of the deep-sea floor. These investigations show that the flux of metals to the deep-sea sediment is mainly dependent on the organic-C and particle flux. In the sediment, the distribution of $\mathrm{Mn}$ and associated trace elements is dependent on redox conditions (PEDERSEN et al., 1986; SHAW et al., 1990). Oxidation of organic matter by the subsequent oxidants oxygen, nitrate, manganese, iron and sulphate determines the sediment chemistry directly and indirectly. In general, pore water profiles indicate that $\mathrm{Cu}$ concentrations are the highest at the sediment-water interface and rapidly decrease with depth. These profiles are explained by the degradation of the organic-Cu carrier during early diagenesis; this results in a release of $\mathrm{Cu}$ into the bottom-water (e.g. Heath and Dymond, 1977; Hein et al., 1979; CAllender

${ }^{*}$ Dept. of Geochemistry. Institute of Earth Sciences, Utrecht University, P.O. Box 80.021, 3508 TA Utrecht, The Netherlands.

$\doteqdot$ Netherlands Institute of Ecology, Centre for Estuarine and Coastal Ecology, Vierstraat 28, 4401 EA Yerseke, The Netherlands. 
and Bowser, 1980; Elderfield, 1981; Klinkhammer et al., 1982; Graybeal and Heath, 1984; Lyle et al., 1984; Pedersen et al., 1986; Heggie et al., 1987; Chester et al., 1988; SHAw et al., 1990). Manganese pore-water concentrations often show an increase with depth (e.g. Froelich et al., 1979; De LANGe, 1986) due to the microbially mediated oxidation of organic matter by solid phase $\mathrm{Mn}$.

In the past, steady state was assumed for most deep-sea sediments. Steady state conditions develop when sedimentation rate and organic-C content of the settling particles remains constant (Froelich et al., 1979). However, recent investigations show that climatically induced variations of organic-C fluxes (Thomson et al., 1984; Pedersen et al., 1986; FInNEY et al., 1988; WALlace et al., 1988) can cause non-steady state diagenesis in deep-sea sediments. At various depths Mn-enrichments were found, related to variations in redox conditions. Similarly, in basin-plains, mass-flows from the shelf to the deep-sea can deposit organic- (and metal-) rich sediment at deep-sea sites. Such a sudden deposition of organic-rich material in an "oxic" environment with a low sedimentation rate initiates a sharp oxidation front as $\mathrm{O}_{2}$-rich bottom-water diffuses into the sediment (e.g. WiLson et $a l ., 1985$; DE LANGE, 1986). Elements mobile under oxidized conditions accumulate below the redox boundary $(\mathrm{U}, \mathrm{V}$ and $\mathrm{Zn})$ during the development of such a progressive oxidation front (JARvis and Higgs, 1987; Thomson et al., 1990; Colley and Thomson, 1990). Fe and $\mathrm{Mn}$, mobilized during anoxic and sub-oxic conditions, subsequently scavenge $\mathrm{Ni}$ and $\mathrm{Co}$ and to a lesser extent $\mathrm{Cu}$. Another result of the emplacement of an organic-rich turbidite is that the underlying sediment becomes reduced and redistribution of transition metals occurs. This can result in the formation of reduction haloes and local trace metal enrichments (HaRTMANN, 1979; JaRvis and Higgs, 1987; Thomson et al., 1989).

We investigated the Madeira Abyssal Plain (MAP) sediments which are composed of three different types of turbidites, namely: organic-rich, volcanic and calcareous turbidites (DE LANGE et al., 1987). These distal turbidites are very homogenous and fine grained. By their nature, these remarkably homogenous turbidites are extremely suited to study the effects of oxidation and the subsequent diagenetic alterations (e.g. Wilson et al., 1986; Prahl et al., 1989; Thomson et al., 1989). Oxidation of the top of these turbidites caused drastic colour changes of the sediment, mostly from brown-pale green (oxidized) to dark green (reduced) (Mrddelburg and DE LANGE, 1988). These colour changes are often accompanied by black or purple diffusive fronts above and below the oxidation front. In addition, some black and purple fronts do not seem to be associated with the brown-green colour transition (JARVIS and HIGGS, 1987).

In this study two sequential extraction techniques were used to investigate the pathways of the trace metal enrichments in MAP sediments. Special attention is given to the characterization of two of these coloured fronts that have developed above and below an oxidation front and one very pronounced front not associated with a colour transition.

\section{MATERIALS AND METHODS}

The MAP is a typical basin parallel to the continental margin and enclosed by the African and the Madeira continental rise in the east and abyssal seamounts in the west (Fig. 1).

The basin is filled with thick, ponded sediments delivered by distal turbidites, with a thickness ranging from a few centimetres to several metres and an average carbonate content of $50-60 \%$. Due to the distal and non-turbulent nature (MCCAvE and JONES, 


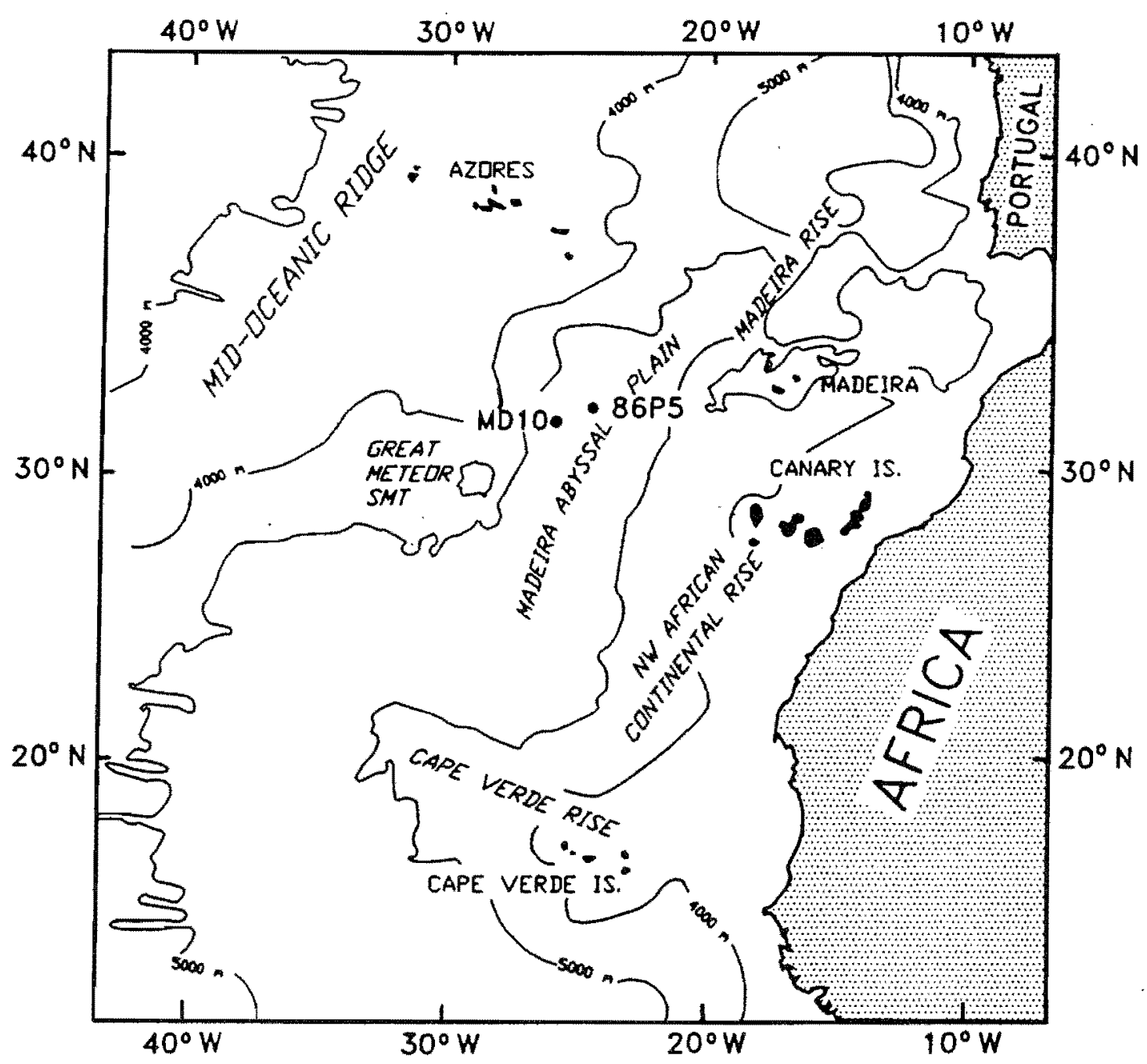

Fig. 1. Map of the Madeira Abyssal Plain and the locations of the cores.

1988) the turbidites are ungraded, homogeneous, fine grained and pertain predominantly to the E-division of the Bouma turbidite facies (Bouma, 1962). The base occasionally grades toward the D-division (WEAvER and KuIJPERs, 1983). Based on their provenance and composition, three major types of turbidites can be distinguished. These are organicrich turbidites, turbidites with a volcanic component, and calcareous turbidites (DE LANGE et al., 1987). The turbidites are intercalated with thin pelagic intervals that can be correlated by their coccolith distributions over very large distances (WEAVER and KuUpers, 1983; Fig. 2.).

Results will be presented from two cores, namely MD10 and PC5. The Stacor piston core MD10 was collected during the 1985 ESOPE cruise with the R.V. Marion Dufresne and is described in detail elsewhere (SchütTenhelm et al., 1989). Piston core PC5 was collected during the 1986 R.V. Tyro cruise. Samples were obtained from the organic-rich $f$-turbidite and calcareous $l$-turbidite (turbidite codes after WEAVER and KUIJPERS, 1983).

The samples selected in core PC5 are located in the $f$-turbidite $\left(135 \mathrm{ky} ; 50-60 \% \mathrm{CaCO}_{3}\right)$ in the region of a sharp colour change at a depth of $741 \mathrm{~cm}$ from pale green at the top towards dark green at the bottom. This depth represents the depth of $\mathrm{O}_{2}$ diffusion after deposition. The $\mathrm{O}_{2}$ penetration stopped after the deposition of a new turbidite and the diagenetic conditions changed to sub-oxic. Due to the development of the progressive 

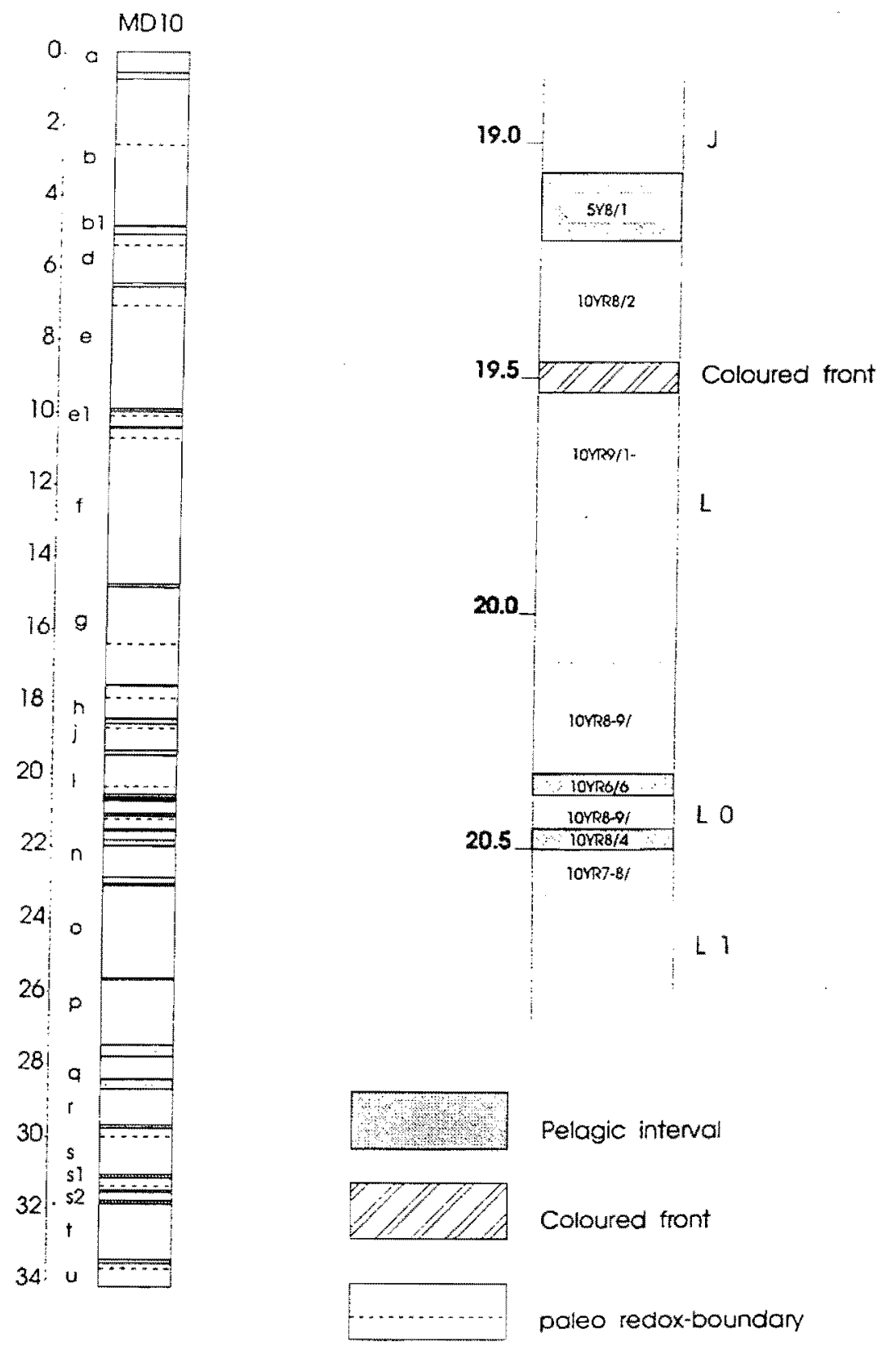

Fig. 2a and 2b. Stratigraphic column of core MD10 with expanded $l$-turbidite and stratigraphic column of the $f$-turbidite of core 86PC5.

oxidation front in the $f$-turbidite, the organic matter content above the colour boundary is only $0.14 \%$, whereas below the boundary the normal value of $1 \% \mathrm{C}_{\text {org }}$ is found (PraHL et al., 1989). The samples were collected at a depth of $720-722 \mathrm{~cm}$ from a thin laminar diffusive black-purple coloured front located above the paleo-oxidation front (front 1) and about $6 \mathrm{~cm}$ below the paleo-oxidation front at $746-748 \mathrm{~cm}$ (front 2) (Fig. 3). These fronts are not isolated curiosities observed only in core PC5, but are found throughout the MAP, often in the region of paleo-redox fronts.

The calcareous turbidite $l(\sim 300 \mathrm{ky})$ in core $\mathrm{MD} 10\left(80-90 \% \mathrm{CaCO}_{3}\right)$ is grey at the top (1925 $\mathrm{cm}$ below core top) and gradually changes into grey-green at the bottom $(2012 \mathrm{~cm}$ below core top). The samples were taken from a distinct, intense black-purple coloured 

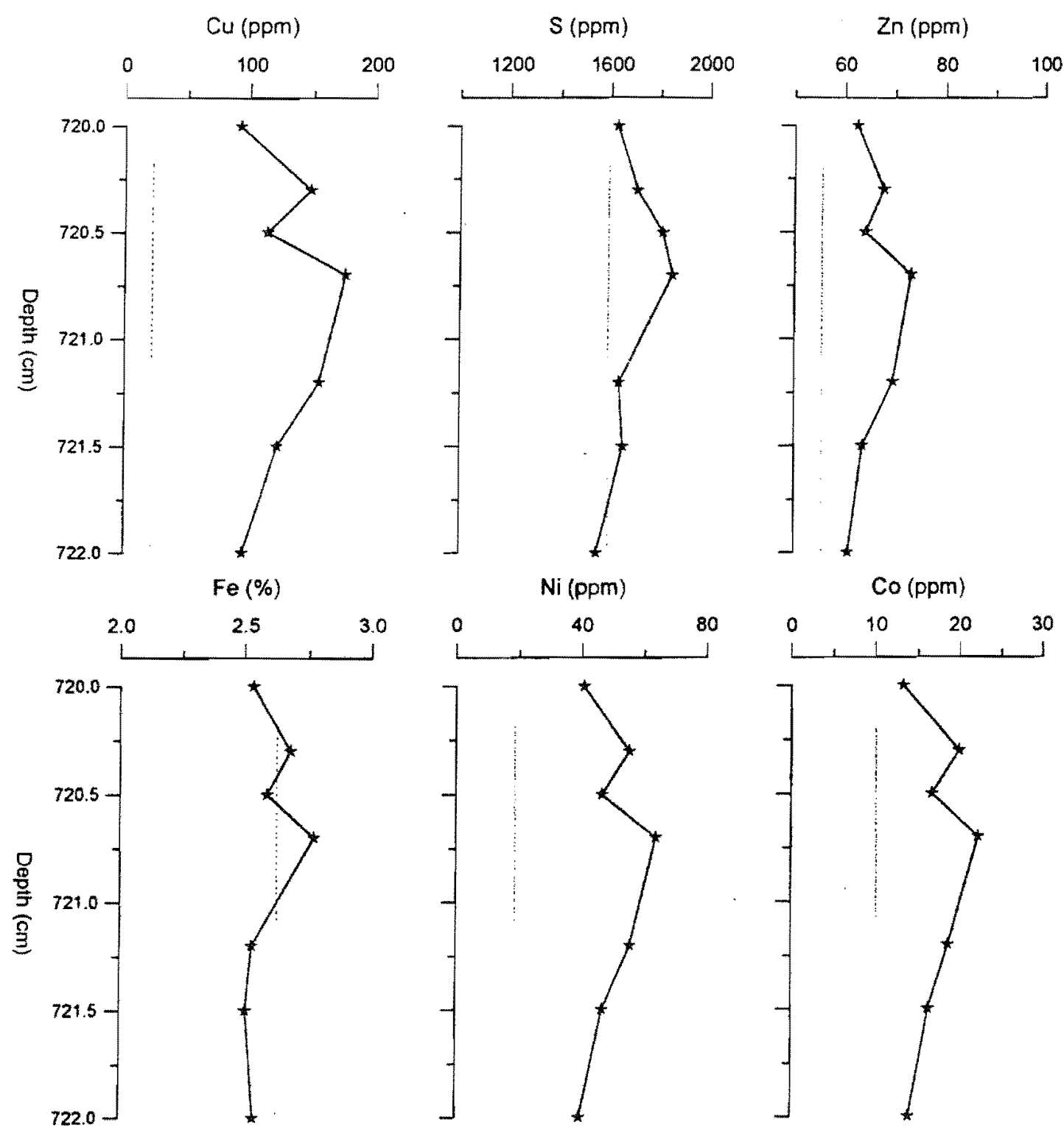

Fig. 3. Concentrations from respectively $\mathrm{Cu}, \mathrm{Co}, \mathrm{Ni}, \mathrm{S}, \mathrm{Fe}$ and $\mathrm{Zn}$ versus depth of front-1 in the $f$-turbidite. The hatched areas display the visible colour change to black-purple.

front, located $21 \mathrm{~cm}$ below the top of the turbidite. The edges of the coloured front were faint. The purple and black colours of all the fronts rapidly disappeared on exposure to air.

On board ship, the $f$-turbidite samples were taken, as soon as possible after recovery of the core PC5, with a bone spatula from the selected purple and black coloured fronts at $\mathrm{mm}$ scale intervals. For the samples of the $l$-turbidite in core MD10, samples were taken within a few months after recovery of the core. The core was always stored at $4^{\circ} \mathrm{C}$, within hermetically closed D-tubes. After opening of the D-tubes and removing of $10-15 \mathrm{~mm}$ from the surface, the front was clearly visible and was subsequently sampled. All samples were transferred into snap-cups that were closed under a $\mathrm{N}_{2}$ atmosphere and stored at $-20^{\circ} \mathrm{C}$.

First we applied a modified "Tessier-type" extraction scheme. This extraction scheme attempts to distinguish between the main mineralogical phases (absorbed/pore-water, carbonate, easy reducible $\mathrm{Fe} / \mathrm{Mn}$ oxides, Fe oxides, pyrite and organic matter, residual 
and silicates) in the sediment. Our results of the $f$-turbidite indicated (see Results section) that the diffusive colour band mainly showed increases in $\mathrm{Cu}$ and $\mathrm{S}$, released during the first extraction steps. Therefore, for analyses of the $l$-turbidite samples of the in core MD10 we applied a more sensitive extraction scheme. This scheme was adapted from Suess (1979) and Middelburg (1991). This extraction procedure was developed specifically for the determination of authigenic mineral phases in anoxic sediments. It therefore might be useful for the extraction of reduced compounds from sub-oxic sediments. Both extraction procedures and the analytical details are briefly summarized in the next sections.

\section{"Tessier-type" extraction}

One to two grams of wet sample were transferred to $50 \mathrm{ml}$ Teflon (FEP) airtight centrifuge tubes in a nitrogen gas $\left(99.9995 \% \mathrm{~N}_{2}\right)$ filled glove-bag and weighed accurately. During extraction the solid-solution ratio was always $>20$. Corrections for water content were made by $\mathrm{Cl}^{-}$analyses of the first extractant $\left(\mathrm{NH}_{4} \mathrm{Ac}\right)$ assuming that all $\mathrm{Cl}^{-}$was derived from seawater. Prior to contact with the samples, the chemical extractants of the first four extraction steps were thoroughly deoxygenated through bubbling with purified $\mathrm{N}_{2}$ gas for several hours. To avoid unintended oxidation during mechanical shaking and sample handling all extractions and handling until step 5 were performed inside a glovebox system (DE LANGE, 1986) under nitrogen atmosphere $\left(\mathrm{O}_{2}<0.0002 \%\right)$.

Following each extraction step the well-closed tubes were centrifuged outside the glovebox and the supernatant was carefully removed and acidified with an appropriate amount of $\mathrm{HCl}$ inside the glove-box. No leakage of the tubes was observed during evacuating the airlock. After each extraction step the samples were washed with redistilled water to remove excess extractant (except extraction step 6) and added to the already obtained supernatant. The final residue (step 6) was quantitatively transferred into a Tefion vessel and dissolved in a $\mathrm{HClO}_{4} / \mathrm{HF} / \mathrm{HNO}_{3}$ mixture, followed by evaporation to dryness. The final solutions were made up in $50 \mathrm{ml} 1 \mathrm{~N} \mathrm{HCl}$. On the basis of a comparison between the sum of all extractions and the independently determined total concentrations, the total weight-loss of sample material was always found $<20 \%$. The extraction scheme is summarized in Table 1.

Table 1. Tessier-type extraction scheme

\begin{tabular}{|c|c|c|c|c|}
\hline Fraction & Extractant & $\mathrm{pH}$ & $\begin{array}{l}\text { Time } \\
\text { (h) }\end{array}$ & Components \\
\hline Exchangeable & $1 \mathrm{NNH}_{4} \mathrm{OAC}$ & 8.2 & 18 & Pore-water cations \\
\hline Carbonatic & $1 \mathrm{NNaOAc}$ & 5.0 & 5 & Carbonates \\
\hline Easily reducible & $0.1 \mathrm{~N} \mathrm{NH}_{2} \mathrm{OH} . \mathrm{HCl}+\mathrm{HNO}_{3}^{*}$ & 2.0 & 7 & Mn-oxides and Fe-hydroxides \\
\hline Moderate reducible & $0.1 \mathrm{~N} \mathrm{NH}_{4}$-oxalate & 2.5 & 5 & $\begin{array}{l}\text { Amorphous Fe-oxides, amorphous clay. } \\
\text { minerals }\end{array}$ \\
\hline Sulphidiclorganic & $\begin{array}{l}30 \% \mathrm{H}_{2} \mathrm{O}_{2}+\mathrm{HNO}_{3}^{*} \text { extracted } \\
\text { after evaporation with } 1 \mathrm{~N} \\
\mathrm{NH}_{4} \mathrm{OAc}\end{array}$ & $\begin{array}{l}2.0 \\
7\end{array}$ & $3^{* 2}$ & Organic matter and mono sulfides \\
\hline Residual & $\begin{array}{l}\mathrm{HF} / \mathrm{HClO}_{4} \mathrm{HNO}_{3} \text { residue } \\
\text { dissolved in } \mathrm{HCl}\end{array}$ & & & Pyrite and crystalline Fe-minerals silicates \\
\hline
\end{tabular}

${ }^{*} \mathrm{HNO}_{3}$ is added to destroy the excess reducing agent. 


\section{Acid gradient extraction}

The samples of the $l$-turbidite were subjected to an acid-gradient extraction (SUESS 1979; Middelburg, 1991). No precautions were taken to avoid the contact of oxygen with the samples.

About $1 \mathrm{~g}$ of a wet fresh sample was weighed in $50 \mathrm{ml}$ Teflon (FEP) airtight centrifuge tubes. After each extraction step the samples were centrifuged and the supernatants were carefully removed. This was followed by washing with distilled water to remove excess extractant. The supernatants of extraction steps 9 and 10 were transferred in a Teflon beaker and evaporated to dryness, and the final solutions were made up in $1 \mathrm{~N} \mathrm{HCl}$. The remaining sediment after step 11 was completely digested by a similar procedure used above. Reagent, concentration, duration and characterization of each extraction step are summarized in Table 2.

\section{Total concentrations}

The sums of the concentrations from the extractions were compared with the total concentrations determined independently. For the samples of the $l$-turbidite sufficient material remained for comparison. Due to the higher sample resolution in the $f$-turbidite, new samples, taken adjacent to the samples used for extraction, were used for this comparison. Total weight loss of sample material during the extraction procedures were estimated to be $<10 \%$. Background concentrations were derived from representative bulk samples taken in the middle of the reduced and oxidized part of the $f$-turbidite. To determine the total concentration, the samples were dried for $24 \mathrm{~h}$ at $105^{\circ} \mathrm{C}$ and thoroughly ground in an agate mortar prior to dissolution in an $\mathrm{HClO}_{4}, \mathrm{HNO}_{3}, \mathrm{HF}$ acid mixture. The final residue was taken up in $1 \mathrm{~N} \mathrm{HCl}$.

All elements used in this study ( $\mathrm{Ca}, \mathrm{Al}, \mathrm{Fe}, \mathrm{S}, \mathrm{Cu}, \mathrm{Co}, \mathrm{Mn}, \mathrm{Zn}$ and $\mathrm{Ni}$ ) were measured with an ARL 34.000 Inductively Coupled Plasma emission spectrometer. Analytical precision and accuracy were determined by replicate analyses of some samples, an international standard (SO-1) and several house standards. The relative standard deviations of SO-1 $(n=15)$ were smaller than $2 \%$ for all elements, and accuracy was better

Table 2. Acid gradient extraction scheme

\begin{tabular}{|c|c|c|c|}
\hline Step & Extraction solvent & $\begin{array}{l}\text { Time } \\
\text { (h) }\end{array}$ & Fraction \\
\hline 1 & Quartz-subboil dest. $\mathrm{H}_{2} \mathrm{O}$ & 8 & Porewater + exchangeable \\
\hline 2 & $\mathrm{NaAc} / \mathrm{HAc}(\mathrm{pH} 5)$ & 16 & Carbonates + exchangeable \\
\hline 3 & $\mathrm{NaAc} / \mathrm{HAc}(\mathrm{pH} 4)$ & 8 & Carbonates \\
\hline 4 & $\mathrm{HAc}(0.5 \mathrm{~N})$ & 16 & Carbonates \\
\hline 5 & $\mathrm{HCl}(0.1 \mathrm{~N})$ & 8 & Carbonates + Fe and Mn (hydr)oxides \\
\hline 6 & $\mathrm{HCl}(0.5 \mathrm{~N})$ & 16 & Fe-oxides \\
\hline 7 & $\mathrm{HCl}(1 \mathrm{~N})$ & 8 & Fe-oxides and sulfides \\
\hline 8 & $\mathrm{HCl}(6 \mathrm{~N})$ & 16 & Sulfides + crystalline Fe-oxides and Fe-silicates \\
\hline 9 & $\mathrm{HF}(20 \%)$ & 16 & Fe-silicates and clay minerals \\
\hline 10 & $\mathrm{HNO}_{3}(60 \%)$ & 16 & Pyrite \\
\hline 11 & $\mathrm{HF} / \mathrm{HNO}_{3} / \mathrm{HClO}_{4}$ & & residual \\
\hline
\end{tabular}


than $4 \%$. The bulk composition of the turbidites from the PC5 core are from a companion study (DE LANGE, in preparation).

It should be noted that the applied extraction methods are operationally defined. Therefore, the subsequent sequentially extracted fractions only partially represent different sedimentary phases. For example, in the Tessier-type scheme, no difference can be made between organic fractions and mono- or disulphide fractions (Table 1; Tessier et al., 1979; VAN VALIN and MoRSE, 1982; RAPIN and Förstner, 1983; MARTIN et al., 1987). Also, liberation of elements during a certain extraction step followed by adsorption by Fehydroxides or clay minerals will lower the recovery of these elements during that step. Moreover, during the acid-gradient extraction, oxidation of the samples could have caused a shift from a sulphide fraction to a more easily extractable fraction (KERSTEN and FörstNer, 1987). Buffering of the $\mathrm{pH}$ due to the dissolution of carbonates in the first three steps of the acid gradient extraction caused a low specificity towards carbonate related fractions.

In general, care must be taken when interpreting the results of a sequentially performed extraction.

\section{RESULTS}

\section{f-turbidite}

Major elements. Major element $(\mathrm{Ca}, \mathrm{Al}, \mathrm{Fe})$ concentrations display small variations over the coloured front. However, the concentration levels between front 1 and front 2 differ slightly (Table 3 ). The carbonate content of front 1 is approximately $5 \%$ lower than that of front 2. The lower carbonate content of the oxidized part is caused by dissolution of carbonate during (oxic) decomposition of organic matter. Due to the closure effect, $\mathrm{Fe}$ (Fig. 3) and $\mathrm{Al}$ concentrations are opposite to the carbonate content. The extraction results are summarized in Table 4.

Iron is mainly present in the residual fraction $\left(\mathrm{Fe}_{\mathrm{res}}>90 \%\right.$ ). Reactive $\mathrm{Fe}$ (easilymoderate reducible fraction) equals about $10 \%$ of the total Fe concentration. (Table 4).

The $\mathrm{Mn}$ content is low (400 ppm). Most $\mathrm{Mn}(80 \%)$ is extracted in the "carbonate fraction" ( $1 \mathrm{~N} \mathrm{NaOAc}, \mathrm{pH}$ ). This suggests that $\mathrm{Mn}$ exists rather than as a carbonate phase than as a Mn-oxide phase (e.g. Boyle, 1983; Thomson et al., 1987). Manganeseoxides in this scheme would be extracted with the Chester-Hughes reagent $(0.1 \mathrm{~N}$ $\mathrm{NH}_{2} \mathrm{OH} . \mathrm{HCl}$ ). The recovery of $\mathrm{Mn}$ for this fraction, however, is only about $40 \mathrm{ppm}$.

Trace elements. The concentration of some trace elements $(\mathrm{Ni}, \mathrm{Co})$ is constant with depth in front 2 but shows some variation in front 1 (Figs 3 and 4 ). In front 1 the highest

Table 3. Main composition of the coloured fronts in the $\mathrm{f}$-and l-turbidite

\begin{tabular}{lccc}
\hline & $\mathrm{Ca}(\%) \pm \mathrm{S} . \mathrm{D}$. & $\mathrm{Al}(\%) \pm \mathrm{S} . \mathrm{D} . \mathrm{Fe}(\%) \pm \mathrm{S} . \mathrm{D}$. \\
\hline Front 1 & $20.3 \pm 0.5$ & $4.7 \pm 0.1$ & $2.6 \pm 0.07$ \\
Front 2 & $21.4 \pm 0.5$ & $4.3 \pm 0.1$ & $2.1 \pm 0.06$ \\
l-turbidite & $35.2 \pm 0.5$ & $1.7 \pm 0.05$ & $0.9 \pm 0.02$ \\
\hline
\end{tabular}


concentrations are found in the middle of the coloured front. $\mathrm{Cu}$ shows distinct peaks in both coloured bands and is up to three times enriched in front 2 (Fig. 4).

The concentration of S almost doubles in front 2 (Fig. 4). The increased concentrations of $S$ in the front correspond with the background values as derived from the reduced bulksamples. The recovery of sulphur of the organic and pyrite fraction $\left(30 \% \mathrm{H}_{2} \mathrm{O}_{2}\right)$ does not contribute much to the total $S$ concentration. The specificity of this step with respect to

Table 4. Summarized results of Tessier-type extraction. The selected intervals are above, inside and below the fronts, respectively. Concentrations in $\mathrm{ppm} ;$ Depth in $\mathrm{cm}$

\begin{tabular}{|c|c|c|c|c|c|c|}
\hline & \multicolumn{3}{|c|}{$86 \mathrm{pc} 5, f$-turbidite, front 1} & \multicolumn{3}{|c|}{$86 \mathrm{pc} 5, f$-turbidite, front 2} \\
\hline & $\begin{array}{c}\text { Depth } \\
719.1-720.1\end{array}$ & $\begin{array}{c}\text { Depth } \\
720.4-721.0\end{array}$ & $\begin{array}{c}\text { Depth } \\
721.3-722.3\end{array}$ & $\begin{array}{c}\text { Depth } \\
745.5-746.0\end{array}$ & $\begin{array}{c}\text { Depth } \\
746.1-746.5\end{array}$ & $\begin{array}{c}\text { Depth } \\
746.8-748.7\end{array}$ \\
\hline Fe Exchangeable & 9 & 5 & 6 & 4 & 14 & 7 \\
\hline Carbonatic & 50 & 21 & 16 & 10 & 101 & 102 \\
\hline Easily reducible & 740 & 666 & 486 & 442 & 1114 & 1284 \\
\hline Moderate reducible & 3014 & 3061 & 2745 & 2506 & 3246 & 2476 \\
\hline Organic/sulphidic & 30 & 21 & 53 & 14 & 27 & 15 \\
\hline Residual & 25,118 & 28,081 & 26,139 & 21,478 & 22,158 & 20,445 \\
\hline S Exchangeable & 1950 & 1610 & 1515 & 1342 & 2248 & 2687 \\
\hline Carbonatic & 0 & 0 & 57 & 0 & 0 & 31 \\
\hline Easily reducible & 0 & 0 & 0 & 0 & 0 & 0 \\
\hline Moderate reducible & 413 & 70 & 63 & 179 & 713 & 86 \\
\hline Organic/sulphidic & 60 & 11 & 0 & 141 & 196 & 227 \\
\hline Residual & 255 & 156 & 207 & 327 & 691 & 1333 \\
\hline \multirow{6}{*}{$\begin{array}{l}\text { Ni Exchangeable } \\
\text { Carbonatic } \\
\text { Easily reducible } \\
\text { Moderate reducible } \\
\text { Organic/sulphidic } \\
\text { Residual }\end{array}$} & 0 & 6 & 2 & 2 & 2 & 0 \\
\hline & 3 & 7 & 5 & 3 & 6 & 5 \\
\hline & 2 & 10 & 6 & 3 & 3 & 3 \\
\hline & 5 & 5 & 5 & 9 & 6 & 5 \\
\hline & 4 & 1 & 1 & 2 & 1 & 2 \\
\hline & 25 & 22 & 24 & 21 & 21 & 25 \\
\hline \multirow{6}{*}{$\begin{array}{l}\text { Co Exchangeable } \\
\text { Carbonatic } \\
\text { Easily reducible } \\
\text { Moderate reducible } \\
\text { Organic/sulphidic } \\
\text { Residual }\end{array}$} & 0 & 0 & 0 & 0 & 0 & 0 \\
\hline & 1 & 4 & 2 & 0 & 2 & 1 \\
\hline & 3 & 6 & 4 & 3 & 5 & 4 \\
\hline & 3 & 3 & 4 & 3 & 3 & 3 \\
\hline & 2 & 1 & 2 & 1 & 2 & 1 \\
\hline & 7 & 8 & 8 & 7 & 7 & 7 \\
\hline \multirow{6}{*}{$\begin{array}{l}\text { Cu Exchangeable } \\
\text { Carbonatic } \\
\text { Easily reducible } \\
\text { Moderate reducible } \\
\text { Organic/sulphidic } \\
\text { Residual }\end{array}$} & 15 & 63 & 32 & 0 & 21 & 0 \\
\hline & 12 & 35 & 24 & 0 & 25 & 2 \\
\hline & 6 & 21 & 27 & 1 & 19 & 3 \\
\hline & 19 & 14 & 15 & 20 & 34 & 17 \\
\hline & 1 & 0 & 0 & 0 & 1 & 1 \\
\hline & 15 & 12 & 12 & 23 & 20 & 28 \\
\hline \multirow{6}{*}{$\begin{array}{l}\text { Zn Exchangeable } \\
\text { Carbonatic } \\
\text { Easily reducible } \\
\text { Moderate reducible } \\
\text { Organic/sulphidic } \\
\text { Residual }\end{array}$} & 1 & 1 & 0 & 0 & 1 & 2 \\
\hline & 5 & 5 & 2 & 3 & 7 & 8 \\
\hline & 7 & 6 & 4 & 11 & 14 & 15 \\
\hline & 18 & 14 & 21 & 19 & 21 & 20 \\
\hline & 9 & 4 & 10 & 4 & 6 & 5 \\
\hline & 45 & 48 & 50 & 42 & 46 & 45 \\
\hline
\end{tabular}



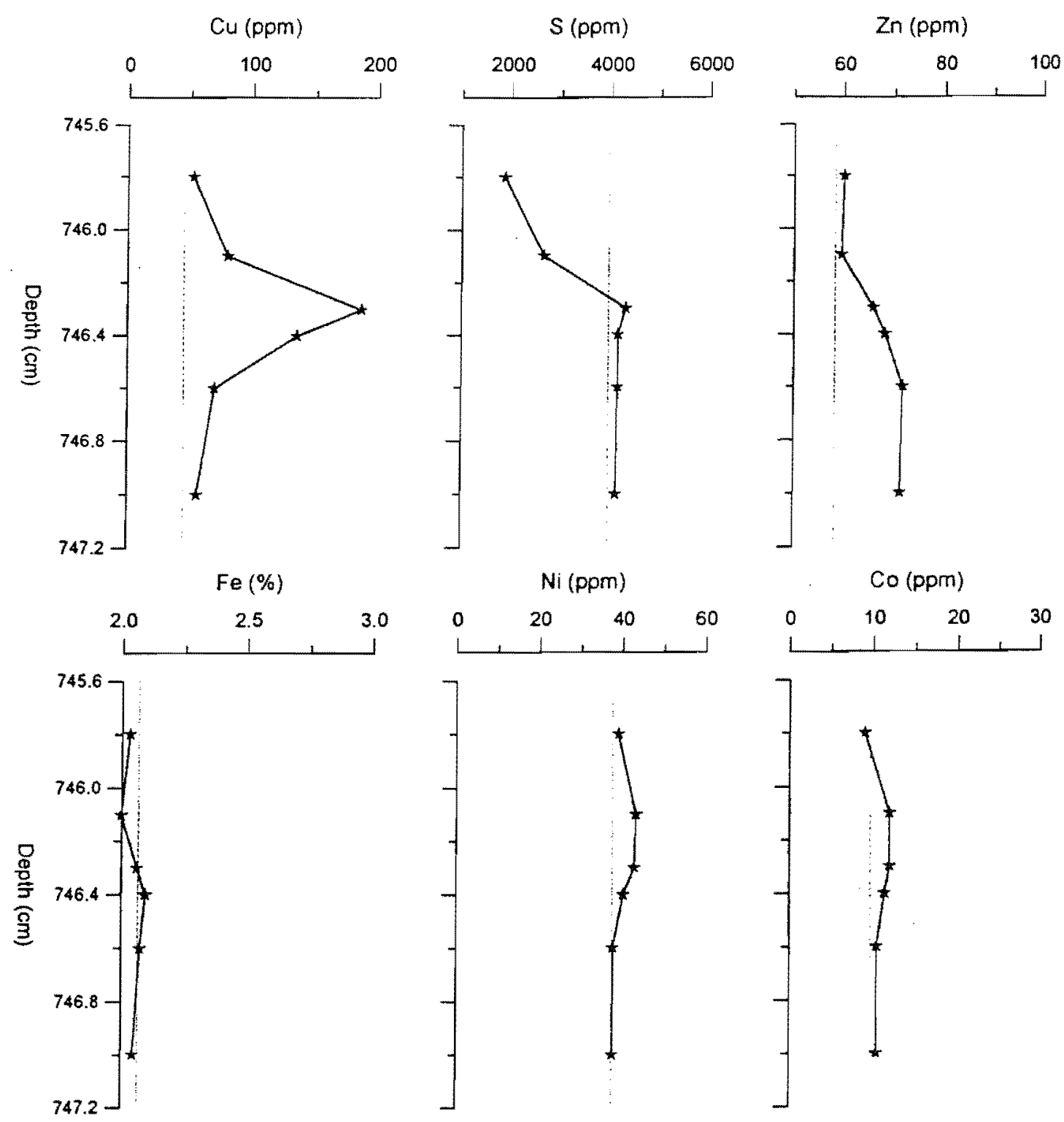

Fig. 4. Concentrations from respectively $\mathrm{Cu}, \mathrm{Co}, \mathrm{Ni}, \mathrm{S}, \mathrm{Fe}$ and $\mathrm{Zn}$ versus depth of front- 2 in the $f$-turbidite. The hatched areas display the colour change to black-purple.

pyrite is not very high. If pyrite is present, most will be extracted in the residual step (TESSIER et al., 1979). In the lower part of front 2 about $50 \%$ is extracted in the residual and organic matter (pyrite) step (Table 4). Therefore, the increase found in total $S$ is possibly due to an increase in pyrite. Note that the highest $\mathrm{S}$ concentration corresponds to the highest $\mathrm{Cu}$ concentration. This increase in $\mathrm{S}$ is closely matched by a small increase in (residual) $\mathrm{Zn}$, but not by $\mathrm{Co}$ and $\mathrm{Ni}$. The distribution of the trace elements $\mathrm{Ni}$, and $\mathrm{Co}$ in the different fractions does not show much variation. Note that for these trace elements a large amount is found in relatively reactive fractions (Table 4).

Surprisingly, the $\mathrm{Cu}$ distribution over the various fractions changes significantly in the coloured fronts (Fig. 6a and b). The $\mathrm{Cu}$ concentration remains constant, only in the residual and oxide fractions. In contrast, the $\mathrm{Cu}$ concentration in the exchangeable, carbonate and easy reducible fractions demonstrates a 10 -fold increase relative to the concentration in the samples taken outside the coloured front, especially in front 2 (Fig. 

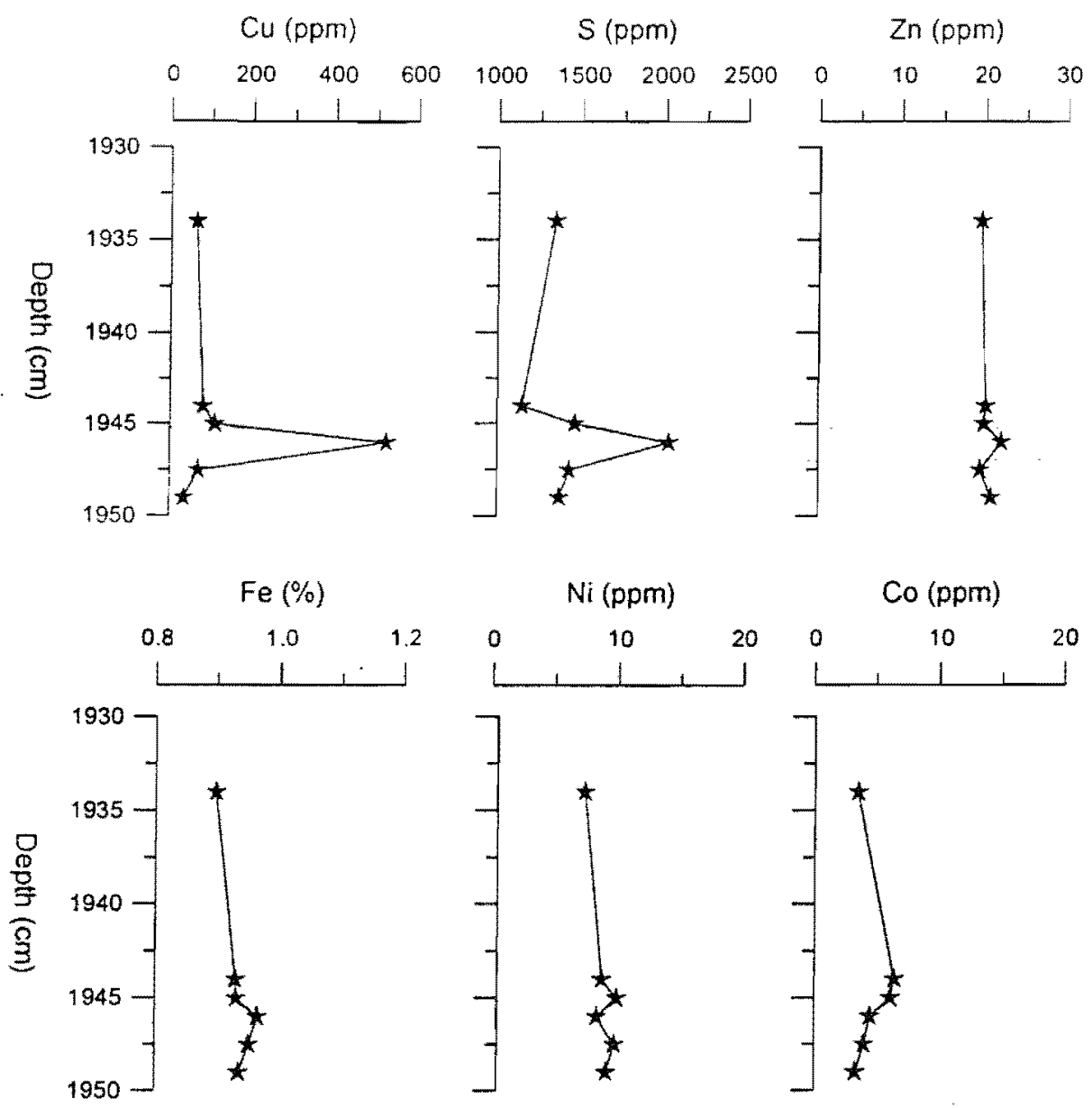

Fig. 5. Concentrations from respectively $\mathrm{Cu}, \mathrm{Co}, \mathrm{Ni}, \mathrm{S}, \mathrm{Fe}$ and $\mathrm{Zn}$ versus depth of the front in the $l$-turbidite.

6a; Table 4). The "excess" $\mathrm{Cu}$ concentration ( $\mathrm{Cu}$ concentration in the peak minus the $\mathrm{Cu}$ concentration outside the coloured front) is about $130 \mathrm{ppm}$.

\section{l-turbidite}

The concentrations of $\mathrm{Co}, \mathrm{Ni}$ and $\mathrm{Zn}$ are constant nearly across the coloured front, whereas those of $\mathrm{Cu}$ and $\mathrm{S}$ display distinct enrichments (Fig. 5). $\mathrm{Cu}$ is about six times enriched compared with the lowest value in this interval and $\mathrm{S}$ about four times. A clear linear relation is observed between the $\mathrm{Cu}$ and $\mathrm{S}$ enrichments (Fig. 7). The distribution of $\mathrm{Cu}$ in the $l$-turbidite follows the same pattern as that found in the $f$-turbidite. In the refractory fractions, residual and oxides fractions, $\mathrm{Cu}$ is constant. In the front, which is represented by sample $55.157, \mathrm{Cu}$ is enriched in the exchangeable-carbonate-easily destructible oxides fractions. The enrichment of $\mathrm{Cu}$ can be attributed almost entirely to the increase of $\mathrm{Cu}$ in the exchangeable-easily soluble oxides-carbonate fractions. Also the concentration of $\mathrm{S}$ is higher in the exchangeable-pore-water fraction in the front (Fig. 8). The $\mathrm{Cu}$ concentration of the mild extracted fraction is about $7.9 \mathrm{mmol} \mathrm{kg}^{-1}$. The excess $\mathrm{S}$ concentration is about $15.6 \mathrm{mmol} \mathrm{kg}-1$. The ratio $\mathrm{Cu}: \mathrm{S}$ is 0.51 .

Due to the high carbonate content $\left(\mathrm{CaCO}_{3}>80 \%\right)$ the first five steps are dominated by a carbonate phase. The high carbonate content probably overloaded the buffer capacity 


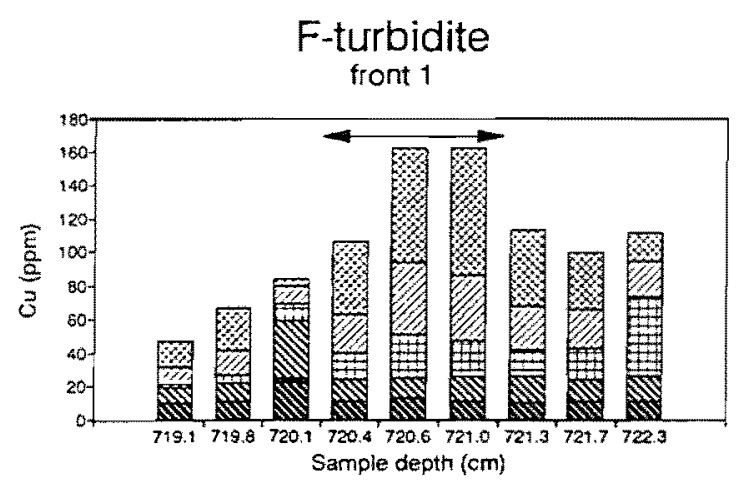

\$6 6

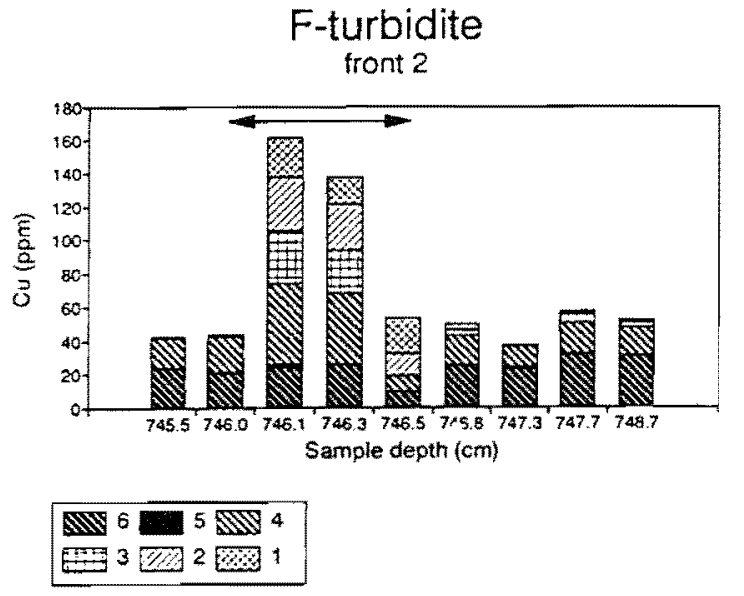

F-turbidite

Fig. 6. The cumulative distribution of Cu from respectively front 1 and 2 in the $f$-turbidite. The arrow indicates the samples with in the front. Note that the samples are not equally spaced. The numbers at the hatches in the legend box correspond to the different extracted steps. $1=\mathrm{NH}_{4} \mathrm{Ac}$; $2=\mathrm{NaAc} ; 3=\mathrm{NH}_{2} \mathrm{OH} . \mathrm{HCl} ; 4=\mathrm{NH}_{4}$-oxalate $; 5=\mathrm{H}_{2} \mathrm{O}_{2} / \mathrm{HNO}_{3} ; 6=\mathrm{HF} / \mathrm{HClO}_{4}$. For a complete extraction scheme the reader is referred to Table 1.

during each of these extractions, raising the $\mathrm{pH}$. The selectivity of the first quartz distilled water step towards exchangeable phases is probably low and only dissolved phases (salts) are extracted. Therefore an overlap between exchangeable sorbed phases and carbonate related phases is suspected in step 2 .

The $\mathrm{HNO}_{3}$ step designed for extraction of pyrite (LORD, 1983) has a low recovery for most elements, suggesting the absence of pyrite.

\section{DISCUSSION}

Two different front types can be distinguished. The first type, exemplified by the front above the redox-front in the $f$-turbidite, is enriched in various trace elements and does not show an association with $\mathrm{S}$. The second type, represented by the fronts in the $l$-turbidite

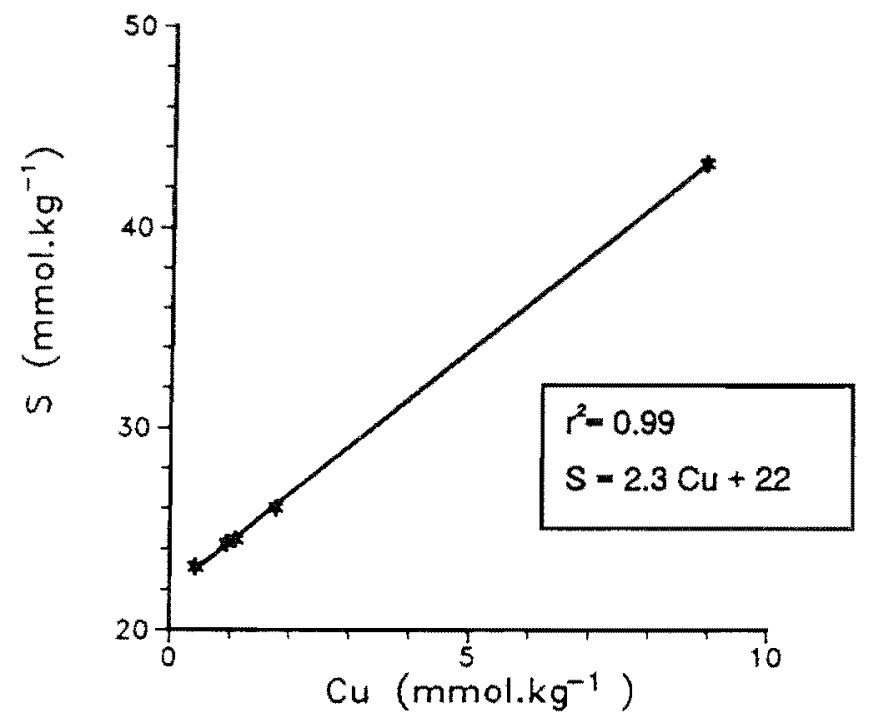

Fig. 7. Cu versus $S$ from the front in the $l$-turbidite. 

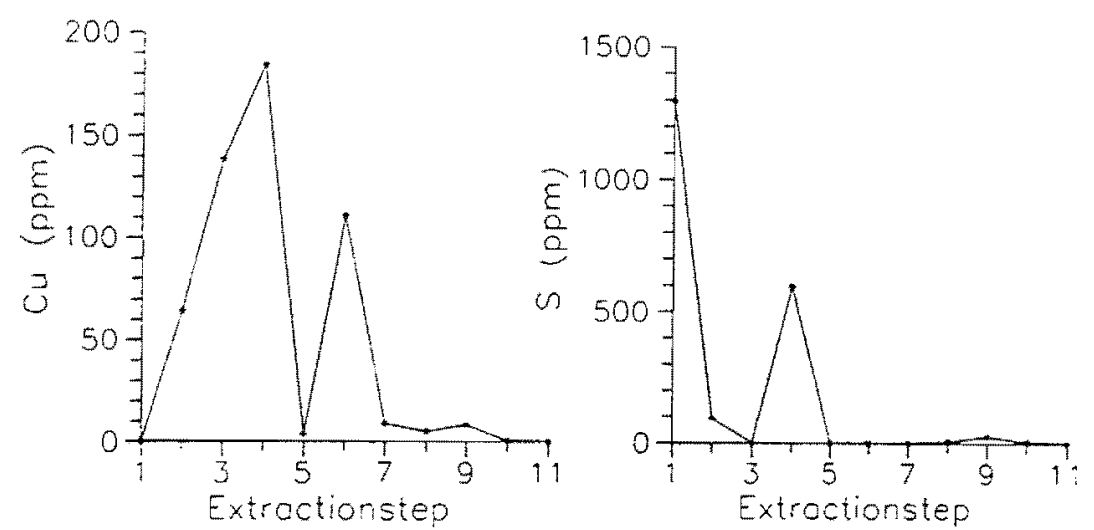

Fig. 8. $\mathrm{Cu}$ and $\mathrm{S}$ release during the successive extraction steps of sample 55.157. The numbers correspond to the extractions steps as summarized in Table 2.

and that below the colour change of the redox front in the $f$-turbidite, is extremely enriched in $\mathrm{Cu}$ and associated with $\mathrm{S}$, but is almost not enriched in other trace metals.

In the interpretation below, we first describe the general diagenetic processes that occur during the emplacement of a turbidite. Subsequently, we discuss the impact of these processes on the distribution of $\mathrm{Cu}$. The point we make is that the front type- 1 is a remnant of the paleo-oxidation front whereas front type- 2 is caused by accumulation of easily extractable and oxidizable $\mathrm{Cu}-\mathrm{S}$ compounds.

\section{Formation of front type-1}

During pelagic sedimentation the rate of accumulation of organic matter is low and all but the most refractory organic matter is oxidized quickly after deposition. Consequently, $\mathrm{O}_{2}$ supplied by diffusion from the bottom-water may persist in the pore water down to considerable depths resulting in an oxic sediment.

After emplacement of a (organic-rich) turbidite, oxidation of excess labile organic matter by bottom-water $\mathrm{O}_{2}$ diffusing downward from the sediment-water interface ("burn-down") can lead to a sharp colour change as observed in the $f$-turbidite. After $\mathrm{O}_{2}$ is exhausted, nitrate, manganese and iron are subsequently used as oxidants in the bacterially mediated decomposition of organic matter.

As a result of the continuous supply of dissolved Fe and $\mathrm{Mn}$ from the underlying reduced sediment and the downward migration of the oxidation front, $\mathrm{Fe}$ and $\mathrm{Mn}$ enrichments are formed near this front. This also may lead to enrichments of elements such as $\mathrm{Ni}, \mathrm{Co}, \mathrm{Zn}$ and $\mathrm{Cu}$ that are involved in the Mn-cycle and easily scavenged by Fe-hydroxides (WILSON et al., 1986; WALLACE et al., 1988). Elements that were previously fixed in the reduced upper part of the turbidite, such as U, V and Cu (Colley and Thomson, 1985; Thomson et al. 1990 ), will be released as the oxidation front passes, and will accumulate just below the redox-boundary.

At deposition of the next turbidite the penetration of $\mathrm{O}_{2}$ stops and the underlying sediment becomes more reduced. Since the organic matter of turbidites is mostly reworked, the underlying sediments will not acquire sulphate reduction but will become post-oxic or sub-oxic. The previously formed Fe and Mn enrichments at the (old) redoxboundary and their associated trace metals will slowly dissolve and redistribute. If the duration of post-oxic conditions is long enough, all the $\mathrm{Fe}$ and $\mathrm{Mn}$ enrichments will 
disappear (FrnNey et al., 1988). Mn is easily adsorbed to carbonates (BoyLe, 1983) and will be decoupled from $\mathrm{Co}, \mathrm{Ni}$ and $\mathrm{Cu}$ that do not have such a high affinity with carbonates.

Redistribution probably takes place along redox-gradients. Because the studied coloured fronts are equilinear to the sediment-water interface, the redox-gradient is coupled to a large scale, long term diagenetic process. The $\mathrm{Cu}, \mathrm{Ni}, \mathrm{Co}$ and $\mathrm{Zn}$ enrichments in the fronts (Fig. 3) are explained by increases of these elements in the exchangeable, carbonate and easily-reducible Fe-hydroxides fractions. Therefore, redox-driven, nonspecific sorption to clays, calcite and, most of all, hydroxides is likely to be the most important process controlling the formation of type- 1 fronts.

\section{Formation of front type-2}

In the MAP sediments, $\mathrm{Cu}$ is delivered by organic-rich turbidites that inherited their Cu-organic complexes content from the shelf sediments (CHEsTER et al, , 1988). Consequently, the organic carrier survives destruction at the sediment-water interface. During the burn down stage of the turbidite some $\mathrm{Cu}$ is probably liberated due to the degradation of the organic carrier. Subsequently, $\mathrm{Cu}$ can be involved in the $\mathrm{Mn}$-cycle or is released into the pore-water. Some $\mathrm{Cu}$ will remain in the anoxic (organic-rich) part of the turbidite. After liberation by the oxidation front, this $\mathrm{Cu}$ can be adsorbed to authigenic clays or react with sulphides. Additionally, $\mathrm{Cu}$ can be complexed again with organic matter and as a result accumulate below the redox-boundary, like U and V (WALlace et al., 1988; Colley and Thomson, 1985, 1990). However, this is probably not the main process for $\mathrm{Cu}$ enrichment in type-2 fronts. The fact that $\mathrm{Cu}$ is the only trace element that is enriched (Figs 4 and 5), and the association of $\mathrm{Cu}$ with $\mathrm{S}$ suggests an additional phase in the $\mathrm{Cu}$ diagenesis. The molar $\mathrm{Cu}: \mathrm{S}$ ratio of $1: 2$ suggests that authigenic $\mathrm{Cu}-\mathrm{S}$ precipitation might explain the formation of type- 2 fronts. In oxic seawater, concentrations of $3-10 \mathrm{nM}$ of $\mathrm{HS}^{-}$have been measured (LuTHER and TSAMAKIs, 1989). SHAw et al. (1990) reported values of dissolved $\mathrm{Cu}$ up to $115 \mathrm{nM}$ in marine sub-oxic pore-waters, although in most cores that they investigated, $\mathrm{Cu}$ concentrations decreased rapidly with depth to $0-10 \mathrm{nM}$. Using a [HS ${ }^{-}$] of $100 \mu \mathrm{M}(10$ times oxic seawater $)$ and a $\left[\mathrm{Cu}^{2+}\right]$ of $100 \mathrm{nM}$ we calculated a near-saturation with respect to $\mathrm{CuS}_{2}$ using the CHARON program (N. M. DE Roolu, Delft Hydraulics Laboratory). However, the concentrations that we assumed are likely to be much lower, especially that of $\mathrm{Cu}$. In seawater over $90 \%$ of the "dissolved" $\mathrm{Cu}$ is complexed with organic ligands lowering the activity of Cu (DONAT and VAN DEN BERG, 1992). Dissolved organic-C levels in sub-oxic pore-waters are usually more than 10 -fold that of seawater. It seems therefore that the formation of authigenic $\mathrm{Cu}$-sulphide in these sub-oxic sediments is not a viable explanation for the observed relation between $\mathrm{Cu}$ and $\mathrm{S}$. This implies that $\mathrm{Cu}-\mathrm{S}$ association must have existed before the formation of the fronts and has accumulated at the present locations of the fronts.

The extent of mobilization of the $\mathrm{Cu}-\mathrm{S}$ association is not limited to an organic-rich turbidite, as demonstrated by the $\mathrm{Cu}-\mathrm{S}$ (Fig. 5) enriched front in the $l$-turbidite. The source of the $\mathrm{Cu}-\mathrm{S}$ association of the coloured front in the $l$-turbidite is probably not the $l$ turbidite itself. This calcareous turbidite is not comprised of (organic-rich) shelf sediments, but has an oceanic western origin where sulphate reduction does not occur (DE LANGe et al., 1987; Schüttenhelm et al., 1989). The origin of the $\mathrm{Cu}-\mathrm{S}$ association therefore must lie in adjacent organic-rich (Cu-bearing) turbidites. The nearest organicrich turbidite is the $l_{1}$-turbidite that is found $80 \mathrm{~cm}$ below the $l$-turbidite (MIDDELBURG 


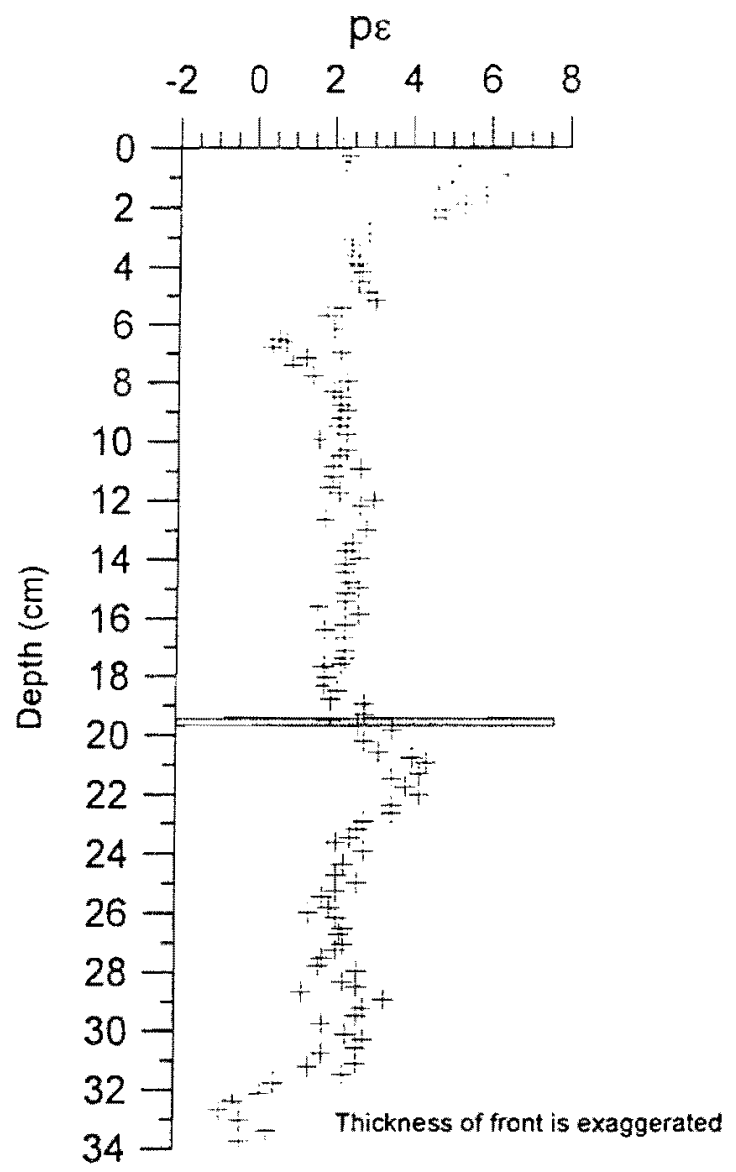

Fig. 9. pe versus depth from core $85 \mathrm{MD} 10$. The hatched area represents the coloured front in the l-turbidite.

and DE LANGE, 1988). This implies that the mobilization distance of the $\mathrm{Cu}-\mathrm{S}$ association is at least $80 \mathrm{~cm}$ (Fig. a). Transport of the $\mathrm{Cu}-\mathrm{S}$ association could occur via intermediate organic (S) components, enhanced by the high affinity of $\mathrm{Cu}$ for organic compounds (RASHID, 1985). Indeed, the extraction of $\mathrm{Cu}$ and $\mathrm{S}$ under mild conditions (Figs 6 and 8 ) and the rapid disappearance of the colour of the front suggests a labile organic or easily oxidizable $\mathrm{Cu}$ compound. The performed extractions, however, do not allow the identification of the exact composition and nature of the $\mathrm{Cu}-\mathrm{S}$ association.

Accumulation of $\mathrm{Cu}$. An indication that relict oxidation fronts could be a source for this accumulation is given by the change in $S$ in front 2 of the $f$-turbidite. Although the colour change in the sediment is governed by the $\mathrm{Fe}^{\mathrm{III}} / \mathrm{Fe}^{\mathrm{II}}$ ratio (LYLE, 1983; DE LANGE, 1988), the extent of the progressive oxidation front may have been deeper. In the initial stage of "burn-down", oxidation of the organic matter and other reduced compounds occurs at a sharp oxidation front, mainly by $\mathrm{O}_{2}$. The classical redox sequence (FroElich et al., 1979) is not observed, as all reactions takes place in a very thin interval. As the front moves down, the flux of oxidants is compensated by the reduced compounds, and the burn-down process will be decelerated. Consequently, the process will incline towards a new steady state situation, As a result, the front will become stretched and the different reactants (Fe, $\mathrm{Mn}, \mathrm{NO}_{3}, \mathrm{O}_{2}$ ) will be separated according to their redox potential. The oxidation of organic matter and reduced Fe can take place at a higher level than the oxidation of pyrite. 
The stepwise increase of S (and Zn, Fig. 4) below the paleo-oxidation front suggests that the oxidation of pyrite occurred deeper than the colour change caused by the transition of $\mathrm{Fe}^{\mathrm{III}}-\mathrm{Fe}^{\mathrm{II}}$. These changes in $\mathrm{p} \varepsilon$ probably are sufficient to accumulate the $\mathrm{Cu}-\mathrm{S}$ association in distinct bands in the region of paleo-oxidation fronts.

The $\mathrm{Cu}-\mathrm{S}$ association in the $l$-turbidite probably also accumulated in response to a redox-gradient. The $\mathrm{p} \varepsilon$ against depth profile (Fig. 9) displays a conspicuous peak at a depth of about $21 \mathrm{~m}$. Remarkably, the Cu-enriched front lies just above this peak, at the steepest incline of this $\mathrm{p} \varepsilon$ gradient. Although the formation of such redox boundary under sub-oxic conditions is yet unclear, these coloured, Cu-enriched layers may be very sensitive indicators for redox changes.

Summarizing, sub-oxic diagenesis can play a very important role in the Cu cycle and could be the most important stage for accumulation of $\mathrm{Cu}$ in marine sediments. It is remarkable that even under sub-oxic conditions in deep-sea sediments significant metal enrichments are formed that persist in a labile phase over a long period and over a large area. However, many questions remain unsolved. Future research must be able to: (1) identify the exact nature of the $\mathrm{Cu}$ carriers and (2) estimate the importance of sub-oxic diagenesis for the accumulation of $\mathrm{Cu}$-rich phases.

Acknowledgements-C. H. van der Weijden, E. Henneke and P. Pruysers are thanked for critically reading the manuscript. S. O. Scholten and G. Frapporti are thanked for drawing Fig. 1. The Dutch Geological Service (RGD) is thanked for the invitation to participate on the 1985 ESOPE Marion Dufresne and the 1986 R.V. Tyro cruise. We would like to thank the crew, technicians and R. T. E. Schüttenhelm and colleagues of the RGD for their cooperation during the 1986 Tyro Cruise. The authors acknowledge the ESOPE funding agencies and the ESOPE scientific party for their help and support. Two anonymous reviewers are thanked for their constructive and helpful comments that improved the manuscript considerably.

\section{REFERENCES}

Bouma A. H. (1962) Sedimentology of some flysh deposits; a graphic approach to facies interpretation. Elsevier, Amsterdam, $120 \mathrm{pp}$.

BOYLE E. D. (1983) Manganese carbonate overgrowth in foraminiferal tests. Geochimica et Cosmochimica Acta, 47, 1815-181.

CAllender E. and C. J. Bowser (1980) Manganese and copper geochemistry of interstitial fluids form manganese nodule-rich pelagic sediments of the northeastern Equatorial Pacific Ocean. American Journal of Science, 280, 1063-1096.

Chester R., A. Thomas, F. J. Lin, A. S. Basaham and G. Jacinto (1988) The solid state speciation of copper in surface water particles and oceanic sediments. Marine Chemistry, 24. 261-292.

COLLey S. and J. Thomsor (1985) Recurrent uranium relocations in distal turbidites emplaced in pelagic conditions. Geochimica et Cosmochimica Acta, 49, 2339-2348.

Colley S. and J. Thomsos (1990) Limited diffusion of U-series radionuclides at depth in deep-sea sediments. Nature, 346. 260-263.

DE LANGE G. J. (1986) Early diagenetic reactions in interbedded pelagic and turbiditic sediments in the Nares Abyssal Plain (western North Atlantic): Consequences for the composition of sediment and interstitial water. Geochimica et Cosmochimica Acta, 50, 2543-2561.

DE LANGE G. J. (1988) Geochemical and early diagenetic aspects of interbedded pelagic/tubiditic sediments in two north atlantic abussal plains. Geologica ultraiectina, $57,190 \mathrm{pp}$.

DE LANGE G. J., I. JARVIS and A. KuIPERS (1987) Geochemical characteristics and provenance of late Quaternary sediment from the Madeira abyssal plain. In: Geology and geochemistry of abyssal plains, N. Atlantic. P. P. E. Weaver and J. Thomson, editors, Geological Society Special Publication, 31, 147-165.

Donat J. R. and C. M. G. VAN DEN BERG (1992) A new cathodic stripping voltammetric method for determining organic copper complexation in seawater. Marine Chemistry, 38. 69-90. 
ELDERFIELD H. (1981) Metal-organic associations in interstitial waters of Narragansett Bay sediments. American Journal of Science, 281, 1184-1196.

Finney B. P., M. W. Lyle and G. R. Heath (1988) Sedimentation at MANOP site H (eastern equatorial Pacific) over the past 4000,000 years: climatically induced redox variations and their effects on transition metal cycling. Paleoceanography, 3, 169-189.

Froelich P. N., G. P. Klinkhammer, M. L. Bender, N. A. Luedther, G. R. Heath, D. Cullen, P. Dauphin, D. HAMmOND, B. HARTMAN and V. MAYNARD (1979) Early oxidation of organic matter in pelagic sediments of the eastern equatorial Atlantic: suboxic diagenesis. Geochimica et Cosmochimica Acta, 43, $1075-1090$.

Graybeal A. L. and G. R. HeAth (1984) Remobilization of transition metals in surficial pelagic sediments from the eastern Pacific. Geochimica et Cosmochimica Acta, 48, 965-976.

HARTMANN M. (1979) Evidence for early diagenetic mobilization of trace metals from discolorations of pelagic sediments, Chemical Geology, 26, 277-293.

HEATH G. R. and J. Dymond (1977) Genesis and transformation of metalloferous sediments from the East Pacific Rise, Bauer Deep and Central Basin, northwest Nazca plate. The Geological Society of America Bulletin, 99, 723-733.

Heggie D., G. P. Klinkhammer and D. Cullen (1987) Manganese and copper fluxes from continental margin sediments. Geochimica et Cosmochimica Acta, 51, 1059-1070.

HEIN J. R., H-W YEH and P. AlEXANDER (1979) Origin of iron-rich montmorillonite from the manganese nodule belt of the North Equatorial Pacific. Clay and Clay Minerals, 27, 185-194.

JARviS I. and M. HıGGS (1987) Trace metal mobility during early diagenesis in distal turbidites: Late quaternary of the Madeira abyssal plain, N. Atlantic. In: Geology and geochemistry of abyssal plains, N. Atlantic, P. P. E. WEAver and J. Thomson, editors, Geological Society Special Publication, 31, 179-215.

KERSTEN P. and U. FörSTner (1987) Effect of sample pretreatment on the reliability of solid speciation data of heavy metals. Implications for the study of early diagenetic processes. Marine Chemistry, 22, $299-312$.

Klinkhammer G. P., D. I. Heggie and D. W. Graham (1982) Metal diagenesis in oxic marine sediments. Earth and Planetary Science Letters, 61, 211-219.

LoRD III, C. J. (1983) A selective and precise method for pyrite determination in sedimentary materials. Journal of Sedimentary Petrology, 52, 664-137.

Luther III G. W. and E. TSamakis (1989) Concentration and form of dissolved sulfide in the oxic water column of the ocean. Marine Chemistry, 27, 165-177.

LYLE M. (1983) The brown-green color transition in marine sediments: A marker of the Fe(III)-Fe(II) redox boundary. Limnology and Oceanography, 28, 1026-1033.

Lyle M., G. R. HeATH and J. M. RobBins (1984) Transport and release of transition elements during early diagenesis: sequential leaching of sediments from MANOP Sites M and H. Part I. pH 5 acetic acid leach. Geochimica et Cosmochimica Acta, 48, 1705-1715.

Martin J. M., P. Nirel and A. J. Thomas (1987) Sequential extraction techniques: Promises and problems. Marine Chemistry, 22, 313-341.

MCCAVE I. N. and K. P. N. Jones (1988) Deposition of ungraded muds from high-density non-turbulent turbidity currents. Nature, 333, 250-252.

Middelburg J. J. (1991) Organic carbon, sulphur, and iron in recent semi-euxinic sediments of Kau Bay, Indonesia. Geochimica et Cosmochimica Acta, 55, 815-828.

Middelburg J. J. and G. J. De LANGe (1988) Geochemical characteristics as indicators of the provenance of Madeira abyssal plain turbidites. A statistical approach. Oceanologica Acta, 11, 1159-164.

Pedersen T. F., J. S. Vogel and J. R. Southon (1986) Copper and manganese in hemipelagic sediments at $21^{\circ} \mathrm{N}$, East Pacific Rise: diagenetic contrasts. Geochimica et Cosmochimica Acta, 50, $2019-2031$.

Prahl F. G., G. J. De Lange, M. Lyle and M. A. Sparrow (1989) Post-depositional stability of long-chain alkenones under contrasting redox conditions. Nature, 341, 434-437.

RAPIN I and U. Förstner (1983) Sequential leaching techniques for particulate metal speciation. The selectivity of various extractants. Symposium: "Heavy metals in the environment.", 1074-1077.

RASHID M . A. (1985) Geochemistry of marine humic compounds. Springer-Verlag, New York, $300 \mathrm{pp}$.

Schüttenhelm R. T. E. G. A. Auffret, D. E. Buckley, R. E. Cranston, C. M. Murray, L. E. Shephard and A. S. Spukstra (1989) Geoscience investigations of two North Atlantic abyssal plains: the Esope International Expedition. Office for Official Publications of the European Communities. Luxembourg, $638 \mathrm{pp}$.

SHAW J., J. M. Gieskes and R. A. JAHNKE (1990) Early diagenesis in differing depositional environments: The response of transition metals in pore-water. Geochimica et Cosmochimica Acta, 54, 1233-1246. 
SuESS E. (1979) Mineral phases formed in anoxic sediments by microbial decomposition of organic matter. Geochimica et Cosmochimica Acta, 43, 339-352.

Tessier F., P. G. C. Camprell and M. Hisson (1979) Sequential extraction procedures for the speciation of particulate trace metals. Analytical Chemistry, 51, 844-851.

Thomson J., T. R. S. Wilson, F. Culkin and D. J. Hydes (1984) Non-steady state diagenetic record in eastern equatorial Atlantic sediments. Earth and Planetary Science Letters, 71, 23-30.

Thomson J., S. Colley, N. C. Higgs, D. J. Hydes, T. R. S. Wilson and J. Sørensen (1987) Geochemical oxidation fronts in NE Atlantic distal turbidites and their effects in the sedimentary record. In: Geology and geochemistry of abyssal plains, N. Atlantic, P. P. E. WeAVER and J. THOMSON, editors, Geological Society Special Publication, 31, 167-177.

Thomson J., N. C. Higgs and S. Colley (1989) A geochemical investigation of reduction haloes developed under turbidites in brown clay. Marine Geology, 89, 315-330.

Thomson J., H. E. Wallace, S. Colley and J. TOOLE (1990) Authigenic uranium in Atlantic sediments of the last glacial stage-a diagenetic phenomenon. Earth and Planetary Science Letters, 98, 222-232.

vaN VALIN R. and J. W. MORSE (1982) An investigation of methods commonly used for the sclective removal and characterization of trace metals in sediments. Marine Chemistry, 11, 535-564.

Wallace H. E., J. Thomson, T. R. S. Wilson, P. P. E. Weaver, N. L. Higgs and D. J. Hydes (1988) Active diagenetic formation of metal rich layers in NE Atlantic sediments. Geochimica et Cosmochimica Acta, 52, $1557-1569$.

Weaver P. P. E. and A. Kuispers (1983) Climatic control of the turbidite depositions of the Madeira Abyssal Plain. Nature, 306, 360-363.

Wilson T. R. S., J. Thomson, D. Colley, D. J. Hydes, N. C. Higgs and J. Sørensen (1985) Early organic diagenesis; the significance of progressive oxidation fronts in pelagic sediments. Geochimica et Cosmochimica Acta, 49, 811-822.

Wilson T. R. S., J. Thomson, D. J. Hydes, S. Coley, F. Culkin and J. Sørensen (1986) Oxidation fronts in pelagic sediments. Diagenetic formation of metal rich layers. Science, 232, 972-975. 